\title{
Margaret McCartney: General practice is still the best job in the world
}

\author{
Margaret McCartney general practitioner, Glasgow
}

Despite political inference, wasteful awareness campaigns, misleading advertisements, poor evidence, and ridiculous media stories, general practice is still the best job in the world. GPs witness the life stories of individuals and families unfolding in real time.

Often you're a port in a storm; sometimes you offer a hand on the rudder, helping to steer the ship. You don't perform complex surgery, and the work isn't glamorous. But it is complex,

requiring incisive intelligence-and, if you want glamour, you can wear whatever shoes you like.

Even though you may think you have little to offer, you may be surprised when, years later, your words are quoted back to you with gratitude. You may do home visits on foot in the snow and slip over, and another patient may come outside to offer you his arm.

When that patient dies, your eyes may prickle from the memory every time you go that way again. Over the years that it takes for a modest person's back-story to emerge, you get to know how extraordinary your patients are. The grit and love and devotion that people use to care about one another leave you quietly amazed.

People choose to tell you about sexual and domestic abuse before they've told anyone else. You get better at managing it, but it never becomes easy. After 10 years' infertility a couple may conceive, their joy uncontained. On the same day you may care for someone else who is dying but isn't ready. When patients you have known for years die, you feel sad and desolate yourself, and then you help the family with their grief.

There are also good deaths, and this teaches you not to fear your own. You become more comfortable with talking less, doing less, and listening more. Occasionally you get the slightly shameful thrill of making a clever diagnosis. But mostly you find pleasure in being an occasional companion to people who need that little steer and support. There is banter and fun with colleagues. And there is fun with your patients, who tease and chide and tolerate you with kindness.

General practice encompasses health and sickness, benefit and harm, living and dying. You are a prescriber, diagnostician, and font of evidence - but also an advocate and avoider of medical harm. You get things wrong sometimes, as everyone does. But you also have days when your heart sings.

Low morale and bad press are putting some young doctors off general practice, and understaffing is probably why six in 10 older doctors are considering early retirement, ${ }^{1}$ why $17 \%$ of Scottish GP practices report at least one vacancy, ${ }^{2}$ and why one in eight GP training places in England goes unfilled. ${ }^{3}$

So, to young doctors, medical students, and teenagers hesitating over university applications: come on in, bring your enthusiasm and vocation, and help us get back the job we love.

Follow Margaret on Twitter, @mgtmccartney

Competing interests: I have read and understood the BMJ policy on declaration of interests and declare the following interests: I'm an NHS GP partner, with income partly dependent on Quality and Outcomes Framework points. I'm a part time undergraduate tutor at the University of Glasgow. I've written two books and earn from broadcast and written freelance journalism. I'm an unpaid patron of Healthwatch. I make a monthly donation to Keep Our NHS Public. I'm a member of Medact. I'm occasionally paid for time, travel, and accommodation to give talks or have locum fees paid to allow me to give talks but never for any drug or public relations company. I was elected to the national council of the Royal College of General Practitioners in 2013 and am chair of its standing group on overdiagnosis. I have invested a small amount of money in a social enterprise, Who Made Your Pants?

The BMSs readers can buy Margaret's new book, Living with Dying, for $£ 7.99$ (RRP £11.99) including UK delivery from www.pinterandmartin. com with checkout code BMJ799.

Provenance and peer review: Commissioned; not externally peer reviewed. Rimmer A. Six in $10 \mathrm{GPs}$ are considering early retirement, BMA survey finds. BMJ Careers
24 March 2014. http://careers.bmj.com/careers/advice/view-article.html?id=20016882.
BMA. Struggle to fill GP vacancies in Scotland. 13 March 2015. http://bma.org.uk/news-
views-analysis/news/2015/march/struggle-to-fill-gp-vacancies-in-scotland.
Rimmer A. One in eight GP vacancies unfilled, despite unprecedented third round of
recruitment. BMJ Careers 24 October 2014. http://careers.bmj.com/careers/advice/viewarticle.html?id=20019782. 
